\title{
A study to assess cardiac diseases in pregnancy and pregnancy outcome
}

\section{Sushma Gore*, Shrikant Warade, Roocha Bramhapurikar}

\author{
Department of Obstetrics and Gynaecology, Shri Vasantrao Naik Government Medical College, Yavatmal, India
}

Received: 21 July 2016

Revised: 02 July 2016

Accepted: 06 August 2016

\section{*Correspondence:}

Dr. Sushma Gore,

E-mail: sushmasarangtarak@gmail.com

Copyright: (C) the author(s), publisher and licensee Medip Academy. This is an open-access article distributed under the terms of the Creative Commons Attribution Non-Commercial License, which permits unrestricted non-commercial use, distribution, and reproduction in any medium, provided the original work is properly cited.

\section{ABSTRACT}

Background: Heart disease has a significant impact on fetal and maternal health during pregnancy, labor and delivery. In India and other developing countries, rheumatic heart disease is most common. Cardiac disorders are observed in approximately $1 \%$ of pregnancies; they account for morbidity and mortality rates. The objective of the study was to analyze the effect of cardiac diseases on maternal and fetal outcome.

Methods: Hospital based cohort study was done for a period of 5 years. All pregnant women with cardiac disease were the study participants. Total numbers of women with cardiac disease were 390.

Results: It was observed that majority of the study participants were suffering with mitral stenois (30\%), followed by mitral regurgitation $(25 \%)$ and mitral strenosis and regurgitation $(12 \%)$. Very few women died because of certain complications, atrial fibrillation (1\%), congestive cardiac failure (1\%) and pulmonary embolism (1\%). The overall perinatal mortality was found to be $4 \%$ in the present study.

Conclusions: Proper screening of the pregnant women to rule out any cardiac disease is required. If timely intervention are taken to treat the pregnant women with cardiac disease the morbidity and mortality in mother and foetus can be prevented to a great extent.

Keywords: Pregnancy, Heart disease, Mitral stenosis

\section{INTRODUCTION}

Cardiac disorders are observed in approximately $1 \%$ of pregnancies; they account for morbidity and mortality rates and pose challenges in management. ${ }^{1-4}$ Diseases of the heart are broadly divided into congenital and acquired. Common congenital heart diseases include atrial septal defect and ventricular septal defect. The acquired group comprises rheumatic heart disease, cardiomyopathies and ischaemic heart disease. ${ }^{5,6}$

Heart disease has a significant impact on fetal and maternal health during pregnancy, labor and delivery. ${ }^{7}$ The majority of women with cardiac disease can tolerate pregnancy successfully without major complications..$^{8-11}$ However, in some of the patients, pregnancy can cause certain therapeutic problems, which may threaten maternal and fetal well being and survival. In the presence of maternal heart disease, the circulatory changes of pregnancy may result in adverse consequences, including death of the mother or fetus. ${ }^{12}$

In India and other developing countries, rheumatic heart disease is most common. ${ }^{13}$ So the present study was done to analyse the influence of cardiac disease on pregnancy with the following objectives.

- To assess the cardiac diseases in pregnancy.

- To analyze the effect of cardiac diseases on maternal and fetal outcome. 


\section{METHODS}

The hospital based cohort study was conducted in the outpatient department of obstetrics and gynecology at Shri Vasantrao Naik Government Medical College Yavatmal, Maharashtra, India. The study was conducted for a period of five years from Jan 2011-Jan2016. During the study period 440 mothers with cardiac disease were identified during routine antenatal check-up. Out of 440 women who had heart disease, 30 aborted and 20 others were lost to follow up. So the final sample size was 390 in which fetomaternal outcome was analyzed. All the pregnant women who visited for routine antenatal check up were screened for cardiac disease were included in the study. Those who were having cardiac diseases were taken as study participants.

Institutional ethics committee permission was obtained. Informed consent was taken from every participant before starting the study.

\section{Methodology}

All the women who visited obstetrics and gynecology OPD for routine antenatal check-up were evaluated by the senior obstetrician as well as the physician for cardiac disease. Functional grading of the cardiac status was made at the first visit according to the New York heart association (NYHA) criteria considering the parity, gestation at first visit and disease status, appropriate counselling was given about continuation or termination of pregnancy with contraception/sterilization. Detailed clinical examination was done at each visit, for evidence of respiratory, lower genital and urinary tract infections and if any. Women are advised additional rest with regular antenatal advice. Those who were identified with underlying cardiac disease were followed up throughout there pregnancy to identify any adverse maternal and fetal outcome. A pre-designed and pre-tested questionnaire was used. The date was entered in MS Excel and analyzed with proportions

\section{RESULTS}

It was observed that majority of the study participants were suffering with mitral stenois $(30 \%)$, followed by mitral regurgitation (25\%) and mitral strenosis and regurgitation (12\%). Among congenital heart diseases atrial septal defect was seen in $14 \%$ of the study participants compared to ventricular septal defect and tetralogy of fallot. In miscellaneous heart condition cardiomyopathy was seen in $5 \%$ of the particiapants (Table 1).

Among all the number of the study participants who were suffering with mitral stenosis in them $62 \%$ were in first gravida while $32 \%$ were in second to fourth gravid which shows that most of them reported during there first pregnancy. Atrial septal defect $(21 \%)$ and tetralogy of fallot (16\%) was reported among only first gravid women. Eissenmenger's syndrome was also seen in first gravida women only. Complete heart block and cardiomyopathy were observed in first gravid as well in second to fourth gravid. Near about $68 \%$ of women with cardiomyopathy were observed in first gravida (Table 2).

Table 1: Distribution of the study participants with cardiac disease.

\begin{tabular}{|c|c|c|}
\hline Cardiac disease & Frequency & Percentage \\
\hline \multicolumn{3}{|c|}{ Rheumatic heart disease } \\
\hline Mitral stenosis & 118 & $(30 \%)$ \\
\hline Mitral regurgitation & 98 & $(25 \%)$ \\
\hline $\begin{array}{l}\text { Mitral stenosis+ } \\
\text { mitral regurgitation }\end{array}$ & 48 & $(12 \%)$ \\
\hline \multicolumn{3}{|c|}{ Congenital heart disease } \\
\hline Atrial septal defect & 56 & $(14 \%)$ \\
\hline $\begin{array}{l}\text { Ventricular septal } \\
\text { defect }\end{array}$ & 21 & $(5 \%)$ \\
\hline Tetralogy of fallot & 16 & $(4 \%)$ \\
\hline \multicolumn{3}{|l|}{ Miscellaneous } \\
\hline $\begin{array}{l}\text { Eissenmenger's } \\
\text { syndrome }\end{array}$ & 5 & $(1 \%)$ \\
\hline Complete heart block & 9 & $(2 \%)$ \\
\hline Cardiomyopathy & 19 & $(5 \%)$ \\
\hline Total & 390 & $100 !$ \\
\hline
\end{tabular}

Table 2: Distribution of study participants with cardiac disease with parity.

\begin{tabular}{|c|c|c|c|}
\hline \multirow{2}{*}{ Cardiac disease } & \multicolumn{2}{|l|}{ Gravida } & \multirow{2}{*}{ Total } \\
\hline & G1 & G2-G4 & \\
\hline \multicolumn{4}{|c|}{ Rheumatic heart disease } \\
\hline Mitral stenosis & $81(68 \%)$ & $37(32 \%)$ & 118 \\
\hline Mitral regurgitation & $48(50 \%)$ & $50(50 \%)$ & 98 \\
\hline $\begin{array}{l}\text { Mitral stenosis+ } \\
\text { Mitral regurgitation }\end{array}$ & $18(37 \%)$ & $30(63 \%)$ & 48 \\
\hline \multicolumn{4}{|c|}{ Congenital heart disease } \\
\hline Atrial septal defect & $31(55 \%)$ & $25(45 \%)$ & 56 \\
\hline $\begin{array}{l}\text { Ventricular septal } \\
\text { defect }\end{array}$ & $\begin{array}{l}21 \\
(100 \%)\end{array}$ & 00 & 21 \\
\hline Tetralogy of fallot & $\begin{array}{l}16 \\
(100 \%)\end{array}$ & 00 & 16 \\
\hline \multicolumn{4}{|l|}{ Miscellaneous } \\
\hline $\begin{array}{l}\text { Eissenmenger's } \\
\text { syndrome }\end{array}$ & $\begin{array}{l}05 \\
(100 \%)\end{array}$ & 00 & 05 \\
\hline $\begin{array}{l}\text { Complete heart } \\
\text { block }\end{array}$ & $4(44 \%)$ & $05(56 \%)$ & 09 \\
\hline Cardiomyopathy & $13(68 \%)$ & $06(32 \%)$ & 19 \\
\hline
\end{tabular}

Majority of the study subjects were falling into class-I $(55 \%)$ as per NYHA guidelines which is followed by class-II $(38 \%)$ and very few in class-III (5\%) and classIV $(2 \%)$ respectively (Table 3$)$.

All the pregnant women with underlying cardiac disease suffered with complications due to cardiac disease such as $4 \%$ were having pregnancy induced hypertension, $8 \%$ 
were anaemic, $1 \%$ of the women were found to have abruption placenta.

Table 3: Classification of study participants as per NYHA.

\begin{tabular}{|lll|}
\hline NYHA classification & Frequency & Percentage \\
\hline I & 215 & $55 \%$ \\
\hline II & 147 & $38 \%$ \\
\hline III & 22 & $5 \%$ \\
\hline IV & 06 & $2 \%$ \\
\hline Total & 390 & $100 \%$ \\
\hline
\end{tabular}

Table 4: Maternal complications.

\begin{tabular}{|lll|}
\hline Complications & Frequency & Percentage \\
\hline Non-cardiac & & \\
\hline PIH & 15 & $(4 \%)$ \\
\hline Anemia & 28 & $(8 \%)$ \\
\hline Abruptio placenta & 02 & $(1 \%)$ \\
\hline Cardiac & & \\
\hline Atrial fibrillation & 03 & $(1 \%)$ \\
\hline Congestive cardiac failure & 04 & $(1 \%)$ \\
\hline Pulmonary embolism & 01 & $((1 \%)$ \\
\hline
\end{tabular}

Table 5: Perinatal outcomes.

\begin{tabular}{|lll|}
\hline Perinatal outcome & Frequency & Percentage \\
\hline IUD & 04 & $(1 \%)$ \\
\hline Still Birth & 01 & $(1 \%)$ \\
\hline Small for gestational age & 02 & $(1 \%)$ \\
\hline $\begin{array}{l}\text { Preterm with very low } \\
\text { birth weight with birth } \\
\text { asphyxia }\end{array}$ & 03 & $(1 \%)$ \\
\hline $\begin{array}{l}\text { Small for date with } \\
\text { disseminated } \\
\text { intravascular } \\
\text { coagulopathy with } \\
\text { intraventricular } \\
\text { haemorrhage }\end{array}$ & 01 & $(1 \%)$ \\
\hline $\begin{array}{l}\text { Birth Asphyxia with } \\
\text { meconium aspiration } \\
\text { syndrome. }\end{array}$ & 01 & $(1 \%)$ \\
\hline $\begin{array}{l}\text { Premature with } \\
\text { respiratory distress } \\
\text { syndrome }\end{array}$ & 02 & $(1 \%)$ \\
\hline
\end{tabular}

Very few women died because of certain complications, atrial fibrillation $(1 \%)$, congestive cardiac failure $(1 \%)$ and pulmonary embolism (1\%) (Table 4).There were few perinatal deaths because of cardiac disease complication pregnancy, such as IUD, still birth, small for gestational age, preterm with very low birth weight with birth asphyxia, small for date with disseminated intravascular coagulopathy with intraventricular haemorrhage, premature with respiratory distress syndrome. All the above mentioned contributed to $1 \%$. The overall perinatal mortality was found to be $4 \%$ in the present study (Table $5)$.

\section{DISCUSSION}

In the present study it was observed that majority of the study participants were suffering with mitral stenois (30\%), followed by mitral regurgitation (25\%) and mitral strenosis and regurgitation (12\%). Among congenital heart diseases atrial septal defect was seen in $14 \%$, where as in another study it was seen the prevalence was high compared to present study were mitral stenosis was seen in $(44.5 \%), 2$ Mitral regurgitation $20.9 \%$, mitral stenosis + mitral regurgitation $13.6 \%$. In case of congenital heart disease. ${ }^{14}$ Atrial septal defect was found in $7.3 \%, 2$ ventricular septal defect 5.5\%, 3 Eisenmenger's syndrome $\left(0.9 \%\right.$ respectively. ${ }^{14}$ In one study done by Konar et al mitral stenosis was seen in $39 \%$ of the study participants which was higher than our study and atrail septal defect was seen in $25 \%$ and ventricular septal defect was seen in $20 \%$ of the study subjects. ${ }^{15}$ In another study it was obsereved that $70 \%$ of the patients of heart disease was of rheumatic origin and rest $30 \%$ of the patients presented with congenital heart disease. Mitral stenosis was the commonest Rheumatic heart disease. ${ }^{17}$

Majority of the study subjects were falling into class-I (55\%) as per NYHA guidelines which is followed by class-II (38\%) and very few in class-III (5\%) and classIV $(2 \%)$ respectively. The study results were similar one study in terms of NYHA classification $70.9 \%$ were in class-I, II- $14.55 \%$ class-III $10 \%$ and class-IV 3.64\%. ${ }^{14}$ In a study done by Konar et it was found that majority were in grade I and II (83. $27 \%)$, III $(15.30 \%)$ and IV 04 $(0.14 \%){ }^{15}$

All the pregnant women with underlying cardiac disease suffered with complications due to cardiac disease such as $4 \%$ were having pregnancy induced hypertension, $8 \%$ were anaemic, $1 \%$ of the women were found to have abruption placenta, similar findings were seen in one study where anaemia was observed in $9.1 \%$ of the study participants which is similar to the present study and PIH was seen in $6.4 \%$ and abruptio placentae $1.8 \% .{ }^{14}$ Where as in one study done by Suman et al anemia was seen in $3 \%$ and PIH in $6 \%$ of the study subjects which is less than our study. ${ }^{16}$ Cardiac complications such as atrial fibrillation, congestive cardiac failure and pulmonary embolism was seen in $1 \%$ of the study participants whereas ARF was found in 3\%. Pulmonary thromboembolism in $4 \%$ and heart failure $6 \%$ which is higher than in our study. ${ }^{14,16}$ In one study most common maternal complication was heart failure in $16.7 \%$ and maternal deaths was found to be $4.8 \%$ which was more than our study.

The overall perinatal mortality was found to be $4 \%$ in the present study such as IUD, still birth, small for 
gestational age, preterm with very low birth weight with birth asphyxia, small for date with disseminated intravascular coagulopathy with intraventricular haemorrhage, premature with respiratory distress syndrome where as in another study it was found that $14 \%$ were still births. ${ }^{16}$ In a study done by Godavari et al Intrauterine deaths was seen in $9.5 \%$ and $42.1 \%$ were preterm babies.

\section{CONCLUSION}

Proper screening of the pregnant women to rule out any cardiac disease is required. If timely intervention are taken to treat the pregnant women with cardiac disease the morbidity and mortality in mother and foetus can be prevented to a great extent. So health education and awareness about underlying cardiac diseases during pregnancy should be done through campaigns.

Funding: No funding sources Conflict of interest: None declared

Ethical approval: The study was approved by the Institutional Ethics Committee

\section{REFERENCES}

1. Cunnigham FG, Leveno KJ, Bloom SJ, Hauth JC, Rouse DJ, Spong CY. Williams: Obstetrics. $23^{\text {rd }}$ edition. United States. McGraw-Hill. Medical Publishing Division. 2010:958.

2. Clark SL. Cardiac disease in pregnancy. Obstet Gynaecol Clin North Am. 1991;18:237-56.

3. Bagde ND, Madhuri N. Clinical profile and obstetric outcome in pregnancies complicated by heart disease: a five year Indian rural experience. Int $\mathrm{J}$ Reprod Contracept Obstet Gynecol. 2013;2(1):52-7.

4. Fernando A, Daftary SN, Bhide AG. Practical guide to high-risk pregnancy and delivery a south Asian perspective. 3rd edition. Elsevier. Elsevier India Private Limited. 2011:506.

5. Zagrosek VR. The task force on the management of cardiovascular diseases during pregnancy of the european society of cardiology (ESC). European Heart Journal. 2011;32:3147-97.

6. Poppas A, Shroff SG, Claudia C, Korcarz JU, David HS, Marshall BD. Serial assessment of the cardiovascular system in normal pregnancy. role of arterial compliance and pulsatile arterial load. Circulation. 1997;95:2407-15.

7. Dutta DC. Heart disease in pregnancy in Konar $\mathrm{H}$ (Eds). Text book of Obstetrics; $4^{\text {th }}$ edition;1998:293298.

8. Sawhney H, Aggarwal N, Suri V, Vasishta K, Sharma Y, Grover A. Maternal and perinatal outcome in rheumatic heart disease. Int J Gynaecol Obstet. 2003;80:9-14.

9. Davies GA, Herbert WN. Assessment and management of cardiac disease in pregnancy. J Obstet Gynaecol Can. 2007;29(4):331-6.

10. Maqueda GI. Practice guideline of Spanish society of cardiology for the management of cardiac disease in pregnancy. Rev Esp Cardiol. 2000;53:1474-95.

11. Scirica BM, Ogara PT. Valvular heart disease in pregnancy. Curr Cardiol Rep. 2006;8:83-9.

12. Samuel C, Siu MD. Adverse neonatal and cardiac outcomes are more common in pregnant women with cardiac disease. Circulation. 2002;105:2179.

13. Ghuge SH, Patil VV, Latti RG, Thorat KD. A comparative study of cardiovascular sympathetic activity in three trimesters of pregnancy. Pravara Med Rev. 2011;3(1):19-23.

14. Koregol M, Mahale N, Nayak R, Bhandary K. Maternal and perinatal outcomes of pregnancies complicated by cardiac disease. Turkish German Gynecol Assoc. 2009;10:30-4.

15. Hiralal K, Chaudhuri S. Pregnancy complicated by maternal heart disease: a review of 281 Women. J Obstetrics Gynecology. 2012;62(3):301-6.

16. Puri S, Bharti A, Puri S, Mohan B, Bindal V, Verma S. Maternal heart disease and pregnancy outcomes. JK Sci J. 2013;15(1):7-10.

17. Nayak RG, Patil SK, Laddad MM. Pregnancy with heart disease outcome. Int J Recent Trends Sci Tech. 2014;11(2):169-72.

Cite this article as: Gore $\mathrm{S}$, Warade $\mathrm{S}$,

Bramhapurikar R. A study to assess cardiac diseases in pregnancy and pregnancy outcome. Int $\mathrm{J}$ Reprod Contracept Obstet Gynecol 2016;5:2960-3. 